\title{
Two new species of Habenaria (Orchidaceae) from the Brazilian cerrado and campo rupestre
}

\author{
J. A. N. Batista ${ }^{1}$, L. B. Bianchetti ${ }^{2}$ \& Z. J. G. Miranda ${ }^{3}$
}

Summary. Two new species, Habenaria ciliatisepala and H. egleriana (Orchidaceae, Orchideae), from the cerrado of central Brazil and campo rupestre of the Espinhaço mountain range in Minas Gerais and Bahia, are described and illustrated.

Key Words. Brazil, campo rupestre, cerrado, Habenaria, new species, Orchidaceae.

The genus Habenaria has a temperate and pantropical distribution and the main centres of diversity are in Brazil, southern and central Africa, and East Asia (Kurzweil \& Weber 1992). Brazil, with 165 - 170 species (Hoehne 1940; Pabst \& Dungs 1975), is the country with the largest number of Habenaria species in the New World and possibly also worldwide. Habenaria is also the largest orchid genus in Brazil. The major treatments of the genus for the country so far are those of Cogniaux (1893) in Flora Brasiliensis, Hoehne (1940) in Flora Brasilica and Pabst \& Dungs (1975) in Orchidaceae Brasilienses.

The main centre of diversity of Habenaria in Brazil is the cerrado, a species-rich savanna vegetation covering 2 million $\mathrm{km}^{2}$ of Central Brazil (Ratter et al. 1997). Among the Habenaria species-rich areas in central Brazil is the core region of the cerrado vegetation, including the "Distrito Federal" [Federal District] where 77 taxa are known (Batista \& Bianchetti 2003) and neighbouring areas in the state of Goiás. In the course of a survey of the orchid flora of this cerrado region, several taxa of Habenaria have been collected that we have been unable to assign to any known New World species in the genus, two of which are described here as new. All cited specimens were seen by the authors.

Habenaria ciliatisepala J. A. N. Bat. E Bianch. sp. nov. in columnae structura haec species nova $H$. mystacina
Lindl. affinis, sed ab hac et ab omnibus speciebus neotropicalibus generis foliis patentibus, lanceolatis, limbo haud cauli adpresso, marginibus sepalorum ciliatis, petalo anteriori appendice dentiformi redacto et labello profunde partito distincta. Typus: Brazil, Distrito Federal, Batista, Proite E Oliveira-Neto 1273 (holotypus BHCB; isotypi AMES, CEN, K, MBM, MO, $\mathrm{RB}, \mathrm{SP})$.

Terrestrial herb, medium-sized. Tuber and roots not examined. Stem erect, $39-61 \mathrm{~cm}$ long, including the inflorescence, $2-3 \mathrm{~mm}$ wide. Leaves $11-15$, lowermost sheath-like, largest at the centre of the stem, \pm spreading, lanceolate, $6.5-12.5 \times 0.6-1.3 \mathrm{~cm}$. Inflorescence 6 - $13 \mathrm{~cm}$ long, many-flowered, congested; bracts broadly lanceolate, $6-21 \times 3.5-7 \mathrm{~mm}$, shorter or the same size as the pedicellate ovary. Flowers $25-$ 53, green, small; pedicellate ovary mostly parallel to the rachis, $8-11 \mathrm{~mm}$ long, ovary slightly arched. Sepals green, slightly mucronate, ciliate; dorsal sepal elliptical, $(2.5-) 3-4 \times 2.5-3.5(-4) \mathrm{mm}$, discreetly ciliate; lateral sepals obliquely oblong-lanceolate to elliptical, reflexed, $4-5.5 \times 2-3 \mathrm{~mm}$, distinctly ciliate. Petals slightly bipartite, base greenish, towards the lobes apex whitish; posterior lobe linear-falcate, (2.5 -) $3-4 \times 1 \mathrm{~mm}$, obtuse to subacute, connivent with the dorsal sepal; anterior lobe reduced to a toothlike projection, inserted at the base of the posterior lobe, $(0.3-) 0.5(-0.8) \mathrm{mm}$ long, somewhat truncate.

\footnotetext{
Accepted for publication July 2008.

1 Universidade Federal de Minas Gerais, Instituto de Ciências Biológicas, Depto. Botânica, Av. Antônio Carlos 6627, Pampulha, C.P. 486, Belo Horizonte, MG, 31270-910, Brazil.

2 Embrapa Recursos Genéticos e Biotecnologia, Parque Estação Biológica, Final Av. W5 Norte, C.P. 02372, Brasília, DF 70770-901, Brazil.

3 Embrapa Cerrados, C.P. 08223, Planaltina, DF 73301-970, Brazil.
} 
Lip distinctly tripartite, base whitish, towards the lobes apex light green; side-lobes erect, reflexed, linearfiliform, 4 - $6 \mathrm{~mm}$ long; mid-lobe linear-ligulate, 4 $6 \times 0.8-1 \mathrm{~mm}$, hook-shaped. Spur pendent, totally or partially covered by the bracts, linear, about the same size as the pedicellate ovary, $9-13 \times 0.7-1 \mathrm{~mm}$, green. Column erect, $2.5 \mathrm{~mm}$ high; connective emarginate, green; auricles fleshy, verrucose, whitish, $0.5 \mathrm{~mm}$ long. Anthers $1.5 \mathrm{~mm}$ high, canals $1-$ $1.2 \mathrm{~mm}$ long; pollinium 2, separated; viscidium $0.15 \times$ $0.15 \mathrm{~mm}$, spaced $1 \mathrm{~mm}$ apart; caudicles $1.5 \mathrm{~mm}$ long; pollinia 4, $1.2-1.5 \times 1 \mathrm{~mm}$. Stigmas 2 , oblong, $2 \mathrm{~mm}$ long, green, receptive surface convex, turned to the sides and frontwards, mostly separate, in contact only at the apex, truncate, uncinate, margins thickened; space between the stigmas heart-shaped; rostellum c. $2 \mathrm{~mm}$ long, green; mid-lobe triangular, fleshy, acute, completely placed between the anthers, $1 \mathrm{~mm}$ long, $0.8 \mathrm{~mm}$ high; side lobes slender, parallel at base, slightly divergent towards the apex, $1-1.2 \times 0.2 \mathrm{~mm}$. Figs. 1 , 2A \& B.

DISTRIBUTION. Brazil, in the core region of the Cerrado biome (Distrito Federal and neighbouring areas in the state of Goiás), the Serra da Canastra in the state of Minas Gerais, and the Espinhaço mountain range in the states of Minas Gerais and Bahia. Map 1.

BRAZIL. Distrito Federal: Plano Piloto, Jan. 1962, E. P. Heringer 10018 (HB); Chapada da Contagem, Poço Azul, 30 Jan. 1993, J. A. N. Batista 405 (CEN); 17 Jan. 1995, J. A. N. Batista 483 (CEN); DF-280, towards Santo Antônio do Descoberto, area of Furnas, 7 March 1998 (fr.), J. A. N. Batista 781 (CEN); Núcleo Bandeirante, Sucupira farm, $15^{\circ} 54^{\prime} 09^{\prime \prime} \mathrm{S}, 48^{\circ} 00^{\prime} 58^{\prime \prime} \mathrm{W}, 13 \mathrm{Jan}$. 1998, B. M. T. Walter et al. 3971 (CEN, SP); Sucupira farm, $15^{\circ} 55^{\prime} \mathrm{S}, 48^{\circ} 02^{\prime} \mathrm{W}, 30$ Dec. 1998, A. B. Sampaio et al. 285 (CEN); Sucupira farm, 18 Dec. 1999, J. A. N. Batista 964 (CEN); BR-060, between the access to Santo Antônio do Descoberto and the GDF tributary post, 27 Jan. 2001, J. A. N. Batista et al. 1183 (CEN); road Plano Piloto-Sobradinho, near Posto Colorado, 3 Feb. 2001, J. A. N. Batista 1192 (CEN); Gama, BR-060, between the access to Santo Antônio do Descoberto at DF-280 and the GDF tributary post, 18 Dec. 2001 (fl.), J. A. N. Batista, K. Proite E O O. B. Oliveira-Neto 1273 (holotype BHCB; isotypes AMES, CEN, K, MBM, MO, RB, SP); Goiás: Serra dos Pirineus, 14 Jan. 1972, H. S. Irwin et al. 34077 (UB); $20 \mathrm{~km} \mathrm{E} \mathrm{of} \mathrm{Pirenópolis,} 14 \mathrm{Jan}$. 1972, H. S. Irwin et al. 34078 (UB); Pirenópolis, 16 Jan. 1991, J. A. N. Batista 165 (CEN); Pirenópolis, Santuário Ecológico do Morro do Cabeludo, 22 Jan. 1995, J. A. N. Batista Eु A. R. C. Lemos 506 (CEN); Pirenópolis, Cachoeira do Abade, 19 Feb. 1995, J. A. N. Batista Ẽ L. B. Bianchetti 544 (CEN); Chapada dos Veadeiros, 25 Jan. 1979, Gates E Estabrook 043 (HB, UB, SP); Chapada dos Veadeiros, 28 Jan. 1993, J. A. N.
Batista E L. B. Bianchetti 395 (CEN); Santo Antônio do Descoberto, 23 Dec. 2002, J. A. N. Batista 1346 $(\mathrm{CEN})$; between Cocalzinho and Pirenópolis, Serra dos Pirineus State Park, 22 Jan. 2005, J. A. N. Batista $\mathcal{E}^{\circ}$ K. Proite 1558 (BHCB); Bahia: Chapada Diamantina, Mun. of Lençois, in the trail between Capão village and Lençois, 14 Sept. 1996, J. A. N. Batista E R. S. Oliveira 625 (CEN); Minas Gerais: Serra da Canastra National Park, 12 March 2000, J. A. N. Batista E A. R. C. Lemos 1065 (CEN); Catas Altas, Serra do

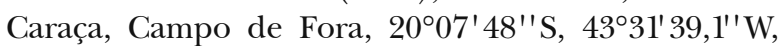
15 Feb. 2005, R. C. Mota 2778 (BHCB); 21 Feb. 2006, J. A. N. Batista E R. C. Mota 1611 (BHCB).

HABITAT. In dry or seasonally humid grassland in dark, sandy-clay soil, usually on slopes and occasionally associated with rock outcrops; $1,000-1,500 \mathrm{~m}$.

CONSERVATION STATUS. Using the IUCN Red List Categories and Criteria (IUCN 2001) the new species can be tentatively classified as Least Concern (LC). The populations of the species appear to be small, and in all collections of the species made by the authors, no more than about 20 flowering individuals were seen for each population. On some occasions, a single or few specimens in flower were observed. However, the species has a broad distribution and is unlikely to suffer any collection pressure. Loss of habitat is the major threat but, fortunately, several known populations of the species are in protected areas.

ETYMOLOGY. The specific epithet refers to the ciliate margin of the sepals.

NOTES. As far as we could determine Habenaria ciliatisepala was first collected in 1962 by Ezechias P. Heringer in the Distrito Federal. This and a few other collections of the species located at $\mathrm{HB}$ and UB were probably examined by Guido Pabst, but were never identified. Distinctive features of $H$. ciliatisepala are the leaves not appressed to the stem, subspreading, lanceolate, the densely and many flowered inflorescence, the conspicuously ciliate margins of the sepals, the anterior petal reduced to a tooth-like appendage, and the lip deeply tripartite (Figs. 1, 2). Combined, these characters render $H$. ciliatisepala a distinct species but its exact affinities are unknown.

Conspicuously ciliate sepals are an uncommon character among new world Habenaria. Habenaria ludibundiciliata J. A. N. Bat. \& Bianch. (Batista \& Bianchetti 2006), usually has sepals with ciliate margins, however in this species the petals are deeply bipartite, the lateral segments of the petals and lip are ciliate and the column is different in that the anthers are spaced one from another (vs placed close together in H. ciliatisepala), the rostellum arms are stout, broader and slightly convergent (vs slender, narrow and slightly divergent) and the stigmas are not uncinate (vs uncinate). In column structure $H$. ciliatisepala is remarkably similar to $H$. mystacina Lindl., particularly in the uncinate stigmas 


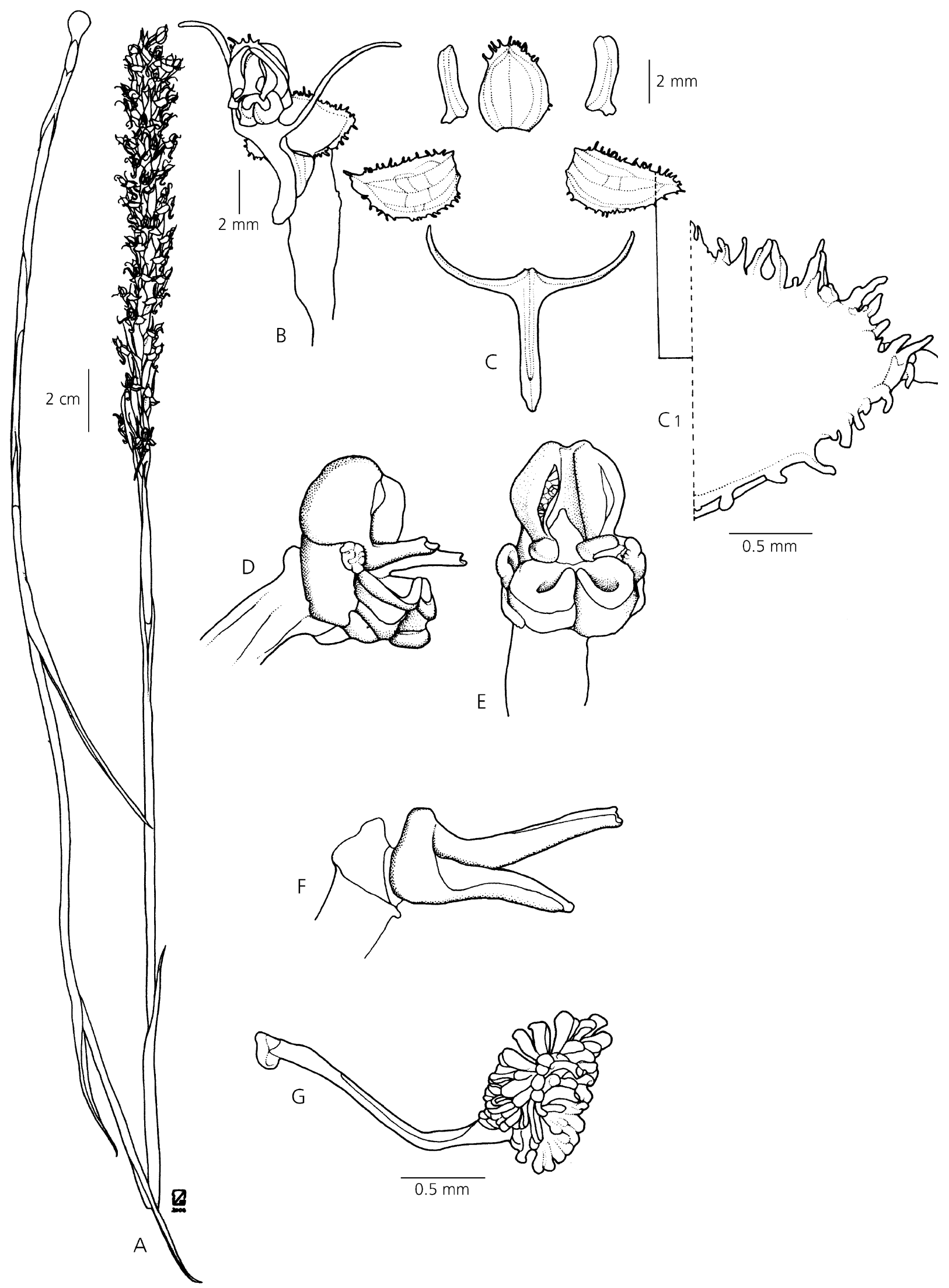

Fig. 1. Habenaria ciliatisepala. A habit; B flower, $3 / 4$ side view; C perianth; D column, side view; E column, front view; $F$ rostellum and upper part of the ovary; G pollinium. Drawn from Batista 1192 and Batista et al. 1273. DRAWN BY ZENILTON J. G. MIRANDA. 

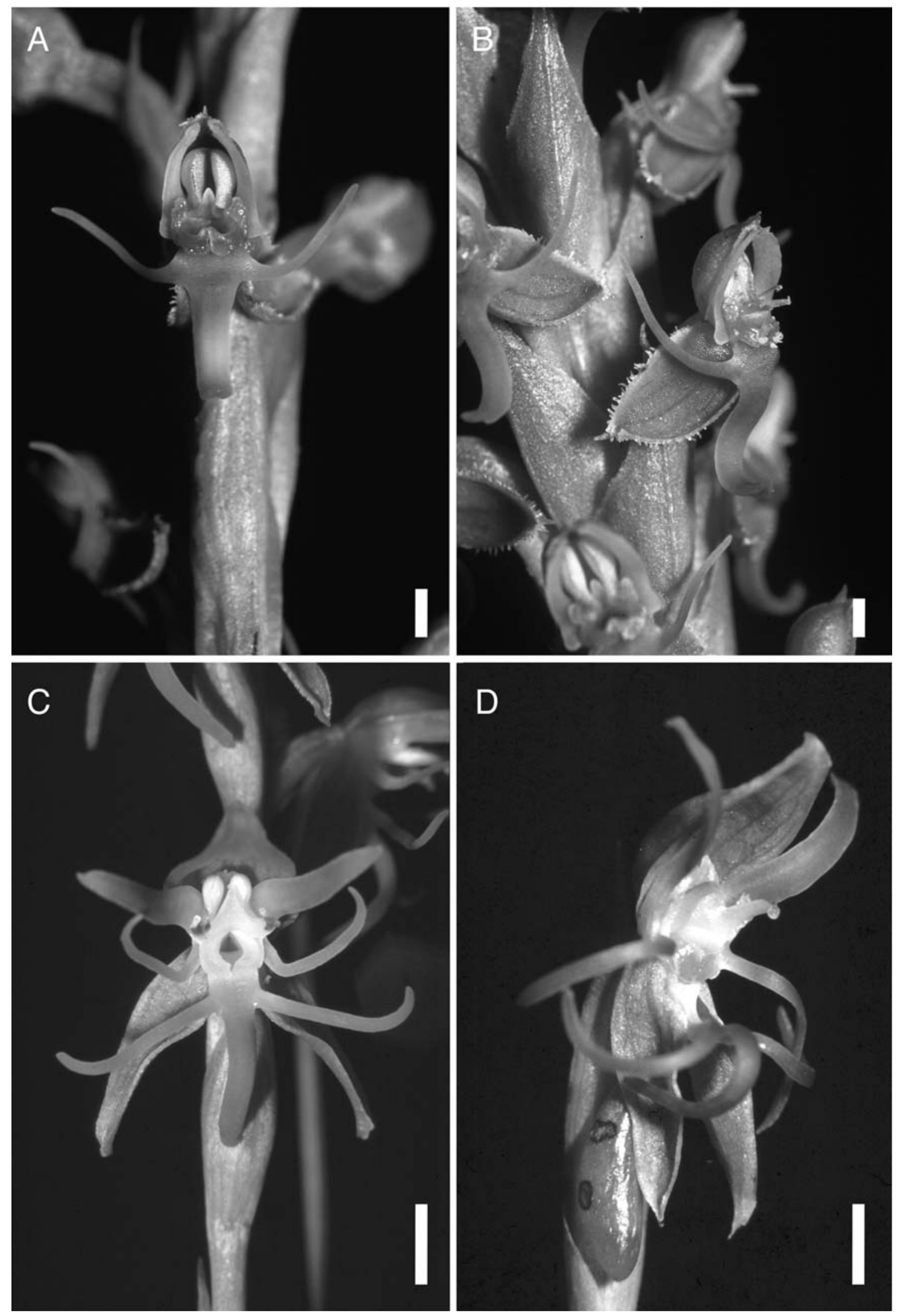

Fig. 2. Flowers, photographed from live specimens. Habenaria ciliatisepala, from the Distrito Federal. A front view; B $3 / 4$ side view. Habenaria egleriana, from Chapada dos Veadeiros, Goiás. C front view; D 3/4 side view. Scale bar $=1 \mathrm{~mm}(A \& B), 3 \mathrm{~mm}(C \& D)$. 


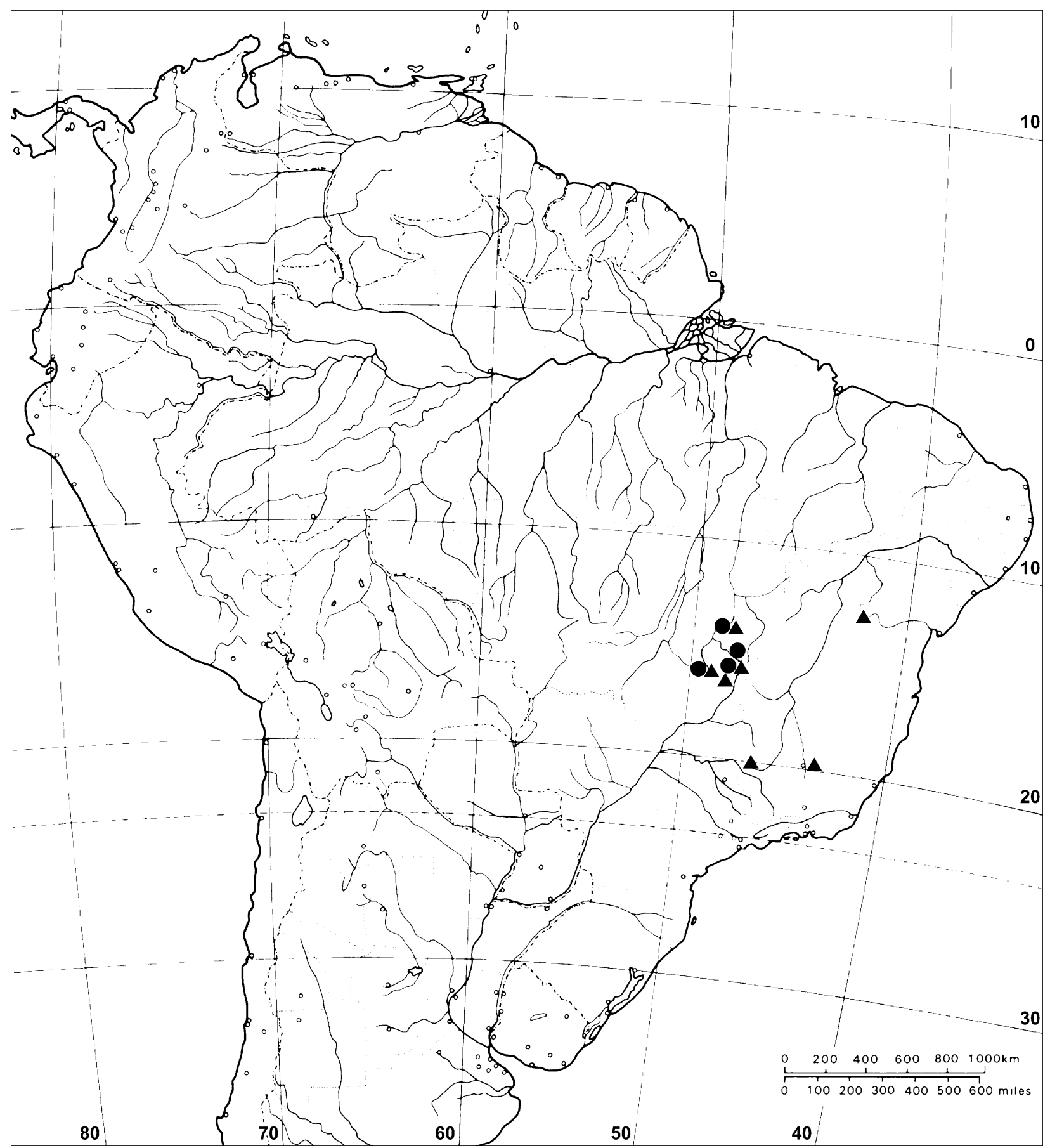

Map 1. Distribution map of Habenaria ciliatisepala $(\boldsymbol{\Lambda})$ and Habenaria egleriana $(\bullet)$. Based on Flora Neotropica base map no 1.

and the space between them (entrance to the spur) that is typically heart-shaped. However, among other differences, $H$. mystacina has deeply bipartite petals and the petals and lip densely pubescent (Batista \& Bianchetti 2006). Despite these differences in the perianth, the striking similarity in column structure suggests a close relationship between $H$. ciliatisepala and H. mystacina. Further studies using macromolecular as well as morphological characters and cladistic analysis may be able to clarify this question.

Habenaria egleriana J. A. N. Bat. E B Bianch. sp. nov. H. sprucei Cogn. affinis sed floribus majoribus (sepalo dorsali 9 - $13 \mathrm{~mm}$ longo), parte indivisa labelli longiore, lobo mediano labelli fortiter curvato, canalibus 


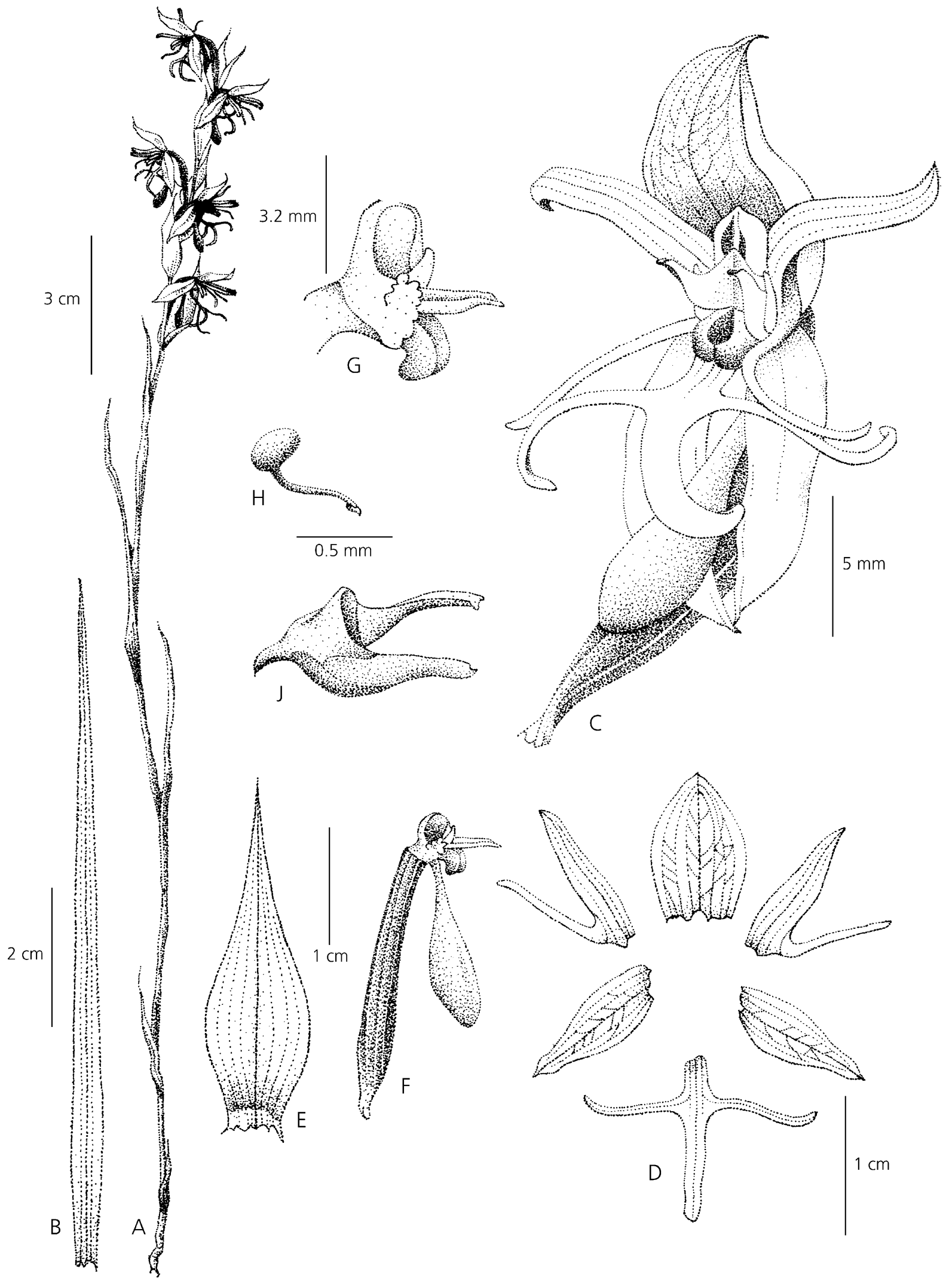

Fig. 3. Habenaria egleriana. A habit; B leaf; C flower, 3/4 side view; D perianth; E bract; F pedicellate ovary, column and spur, side view; G column, side view; H pollinium; J rostellum, side view. Drawn from Batista \& Pansarin 1132. DRAWN BY ZENILTON J. G. MIRANDA AND MARIA HELENA BURIAN. 
antherarum longioribus (3.5 - $4 \mathrm{~mm}$ longi), stigmatibus separatis, connectis solum ad apicem differt. Nota solum in regione centrali in Cerrado bioma. Typus: Brazil, Goiás, Batista E $\mathcal{E}$ Pansarin 1132 (holotypus BHCB; isotypi AMES, CEN, K, MBM, MO, RB, SP).

Terrestrial herb, medium-sized. Tuber and roots not examined. Stem erect or slightly flexuose, $(16-) 26-$ $42(-55) \mathrm{cm}$ long, including the inflorescence, $1-2$ (-3) $\mathrm{mm}$ wide. Leaves $5-7$, lowermost sheath-like, largest at the centre of the stem, linear, $4.5-12$ $(-19) \times 0.4-0.6(-0.8) \mathrm{cm}$. Inflorescence $5-15 \mathrm{~cm}$ long, few-flowered, lax, occasionally secund. Bracts ovate to broadly lanceolate, acuminate, $12-37 \times 5-$ $12 \mathrm{~mm}$, the same size or longer than the pedicellate ovary. Flowers $3-8(-11)$, greenish; pedicellate ovary mostly parallel to the rachis, $15-21 \mathrm{~mm}$ long; ovary slightly arched. Sepals light-green, the veins slightly marked in darker green, mucronate, smooth; dorsal sepal ovate-lanceolate, $9-13 \times 5.5-7(-9) \mathrm{mm}$; lateral sepals obliquely lanceolate, deflexed, $9-12$ $(-14) \times 3.5-4(-5.5) \mathrm{mm}$. Petals distinctly bipartite, whitish at base, green towards the lobe apex; posterior lobe linear-falcate, $(8-) 9-11(-14) \times 1-1.5$ $(-2) \mathrm{mm}$, obtuse to subacute, ascending, for the most part free from the dorsal sepal; anterior lobe reflexed, linear-filiform, inserted at the base of the posterior lobe, $8-10(-11) \mathrm{mm}$ long. Lip distinctly tripartite, whitish at base, green towards the lobe apex; undivided basal part prominent, $2-3(-4) \times 1-1.5$ (-2) $\mathrm{mm}$; lateral lobes perpendicular to the mid-lobe, linear-filiform, $6-9.5 \mathrm{~mm}$ long; mid-lobe linear, strongly reflexed, somewhat $\mathrm{S}$ shaped, $(6-) 7-8$ $(-9.5) \times 1-1.5 \mathrm{~mm}$. Spur pendent, totally or partially covered by the bracts, clavate, shorter than the pedicellate ovary, $8-11(-13) \mathrm{mm}$ long, green, base $0.8-1 \mathrm{~mm}$ wide, apex $2-3(-4.5) \mathrm{mm}$ wide. Column erect, $4 \mathrm{~mm}$ high; connective emarginate, green; auricles fleshy, verrucose, whitish, $2.5 \mathrm{~mm}$ long. Anthers $2 \mathrm{~mm}$ high, canals $3.5-4 \mathrm{~mm}$ long; pollinium 2, separated; viscidium $0.5 \times 0.5 \mathrm{~mm}$, spaced $3 \mathrm{~mm}$ apart; caudicles 3 - $4 \mathrm{~mm}$ long; pollinia $2 \times 1.2 \mathrm{~mm}$. Stigmas 2, $4 \mathrm{~mm}$ long, green, receptive surface convex, turned to the sides or frontwards, mostly separate, in contact only at the apex, $2.5 \times 1.3 \mathrm{~mm}$; rostellum $5 \mathrm{~mm}$ long, green; mid-lobe triangular, fleshy, acute, partially projected beyond the anthers, $2 \mathrm{~mm}$ long, 2.5 $2.8 \mathrm{~mm}$ high; side lobes parallel throughout, $3 \mathrm{~mm}$ long. Figs. 2C \& D, 3.

DISTRIBUTION. Brazil, in the core region of the cerrado biome, including the Distrito Federal and neighbouring areas in the state of Goiás (Chapada dos Veadeiros and the region of Pirenópolis). Map 1.

BRAZIL. Distrito Federal: Reserva Ecológica do Guará, 23 Nov. 1989 (fl.), J. A. N. Batista. 016 (CEN); Lago Sul, QI-17, near Gama stream, 4 Jan. 1995, R. S. Oliveira 062 (UB); 13 Dec. 1998 (fl.), J. A. N. Batista et al. 805 (CEN); Goiás: 9 km S of Corumbá de Goiás, 2 Dec. 1965, H. S. Irwin et al. 10946 (UB, NY, HB, IAN); Chapada dos Veadeiros, 9 Feb. 1966, H. S. Irwin et al. 12385 (UB); Alto Paraíso, on the road to Colinas, 2 Dec. 1992, G. Hatschbach et al. 58368 (MBM); Chapada dos Veadeiros, 27 Jan. 1993 (fl.), J. A. N. Batista E L. B. Bianchetti 389 (CEN); 20 km NW of Corumbá de Goiás, near Pico dos Pirineus, 26 Jan. 1968, H. S. Irwin et al. 19246 (NY, HB, RB, UB) (at UB mixed with $H$. schwackei); 18 km E of Pirenópolis, Serra dos Pirineus, 15 Jan. 1972, H. S. Irwin et al. 34234 (UB, NY, HB); Pirenópolis, 16 Jan. 1991 (fl.), J. A. N. Batista 171 (CEN); 17 Jan. 1992 (fl.), J. A. N. Batista 246 (CEN); Pirenópolis, Morro do Cabeludo, 19 Feb. 1995 (fl.), J. A. N. Batista E L. B. Bianchetti 535 (CEN); $29 \mathrm{~km}$ from Cavalcante, towards São Domingos region, 31 Dec. 1998 (fl.), J. A. N. Batista 821 (CEN); GO-118, 5 km N of São Gabriel de Goiás, 16 Jan. 1999 (fl.), J. A. N.

Table 1. Diagnostic characters for Habenaria egleriana and H. sprucei.

\begin{tabular}{lll}
\hline \hline & H. egleriana & H. sprucei \\
\hline Dorsal sepal & $9-13 \times 5.5-7(-9) \mathrm{mm}$ & $6.5-8 \times 4.5-6 \mathrm{~mm}$ \\
Lateral sepals direction & Deflexed & Not or little deflexed, spread \\
Lip midlobe & Strongly curved & Not curved, straight \\
Lip undivided basal part length & Prominent, $2-3(-4) \mathrm{mm}$ & $1-2 \mathrm{~mm}$ \\
Anther canals length & $3.5-4 \mathrm{~mm}$ & $1.5-1.8 \mathrm{~mm}$ \\
Viscidia spaced from each other & $3 \mathrm{~mm}$ & Small, $0.7 \times 1.3 \mathrm{~mm}$ \\
Auricles & Prominent, 2.5 mm long & Closely parallel, forming a single receptive \\
Stigmas & Mostly separate, in contact only at the apex & surface \\
& & $3.5 \mathrm{~mm}$ \\
Rostellum length & 5 mm & Completely placed between the anthers \\
Rostellum midlobe & Partially projected beyond the anthers & North Brazil (AM, AP, MA, PA, RR), French \\
Distribution & Central Brazil (DF, GO) & Guiana, Guyana, Surinam and Venezuela \\
& &
\end{tabular}

Abbreviations for the Brazilian states: Amazonas (AM), Amapá (AP), Distrito Federal (DF), Goiás (GO), Maranhão (MA), Pará (PA) and Roraima (RR). Material examined of Habenaria sprucei: BRAZIL. Maranhão, R. S. Oliveira Ẽ E. Gonçalves 284 (CEN); Roraima, J. B. F. da Silva 847 (MG); L. B. Bianchetti 1719a (CEN). 
Batista et al. 856 (CEN); Municipality of Alto Paraíso, GO-118, 9 km S of Alto Paraíso, 8 Jan. 2001 (fl.), J. A. N. Batista $\mathcal{E}$ E. R. Pansarin 1132 (holotype BHCB; isotypes AMES, CEN, K, MBM, MO, RB, SP); Mun. Alto Paraíso, $19 \mathrm{~km} \mathrm{~N}$ of Alto Paraíso, 10 Jan. 2001 (fl.), J. A. N. Batista E̋ E. R. Pansarin 1158 (CEN); Mun. of Teresina de Goiás, GO-118, 26 km N of Alto Paraíso, 9 Feb. 2004 (fl.), J. A. N. Batista et al. 1483 (CEN); Alto Paraíso, on the road Alto Paraíso-São Jorge, $14^{\circ} 09^{\prime} 36^{\prime \prime} \mathrm{S}$, 47³6'23''W, 26 Jan. 2001, B. M. T. Walter et al. 4818 (CEN).

HABITAT. In seasonally humid grassland, in humic, dark, sandy-clay soil, frequently associated with small mounds of earth known as 'murundus'; 1,000 - 1,250 m.

CONSERVATION STATUS. Using the IUCN Red List Categories and Criteria (IUCN 2001) the new species can be tentatively classified as Vulnerable, VU (criteria $\mathrm{B} 1 \mathrm{ab}(\mathrm{iii})+2 \mathrm{ab}(\mathrm{iii})$; $\mathrm{C} 2 \mathrm{a}(\mathrm{i}))$. Loss of habitat is the major threat as the seasonal humid campos favoured by the species are also particularly favoured for agriculture. Fortunately, several populations of the species are in protected areas in the Chapada do Veadeiros National Park and the Serra dos Pirineus State Park, both in the state of Goiás.

ETYMOLOGY. The new species is named in honour of Ione Egler, coordinator of the Biodiversity Policies and Programs of the Ministry of Science and Technology, as recognition for her commitment and support for the development of biodiversity research in Brazil.

NOTES. As far as we could determine Habenaria egleriana was first collected in 1965 by H. S. Irwin in Corumbá de Goiás, state of Goiás. At that time collections of the species were identified by G. F. J. Pabst primarily as $H$. leaona Schltr., now a synonym of H. sprucei Cogn. according to Renz (1992), and to a lesser extent also as $H$. lavrensis Hoehne. An illustration of a dissected flower of $H$. egleriana can be found in Orchidaceae Brasilienses (Pabst \& Dungs 1975: fig. 123) as H. leaoana. Habenaria egleriana was recorded as $H$. aff. sprucei in the checklist of the Orchidaceae of the Distrito Federal (Batista \& Bianchetti 2003). In accordance with Pabst's determinations, the species most similar to H. egleriana appears to be H. sprucei, but the two species can be easily distinguished by the characters outlined in Table 1 . The identification as $H$. lavrensis is unwarranted, as this species has the inflorescence congested, with the flowers superposed (vs little superposed and frequently one-sided in $H$. egleriana), petals and lip completely white (vs green), the posterior petal connivent with the dorsal sepal (vs free and reflexed), the anterior petal usually longer than the posterior petal (vs shorter), the spur not or only slightly clavate (vs strongly clavate) and the rostellum midlobe completely placed between the anthers (vs partially projected in H. egleriana), among other differences.

According to the infrageneric treatment of the genus for Brazil (Cogniaux 1893), H. egleriana is best placed in sect. Nudae Cogn.

\section{Acknowledgements}

The authors thank the curators of BHCB, CEN, HB, IAN, MBM, MG, NY, RB, SP and UB for the loan of material or for providing access to their collections, Tarciso Filgueiras for the Latin diagnoses, Maria Helena Burian for finishing the illustration of $H$. egleriana and Maria Carolina A. Luque for revising the English.

\section{References}

Batista, J. A. N. \& Bianchetti, L. B. (2003). Lista Atualizada das Orchidaceae do Distrito Federal. Acta Bot. Bras. 17: 183 - 201.

\&___ (2006). The Brazilian Habenaria (Orchidaceae)

with hairy segments. Sitientibus ser. Ci. Biol. 6: $9-23$.

Cogniaux, A. (1893). Orchidaceae. Habenaria. In: C. F. P. Martius, A. G. Eichler \& I. Urban (eds), Flora Brasiliensis 3 (4): 18 - 102, tab. 3 - 18. F. Fleischer, Munich.

Hoehne, F. C. (1940). Orchidaceas, Habenaria. In: F. C. Hoehne (ed.), Flora Brasilica 12 (1): 52 - 254, tab. 11 - 122. Secretaria da Agricultura, Indústria e Comércio de São Paulo, São Paulo.

IUCN (2001). IUCN Red List Categories and Criteria, Version 3.1. IUCN Species Survival Commission, Gland, Switzerland.

Kurzweil, H. \& Weber, A. (1992). Floral morphology of southern African Orchideae. II. Habenariinae. Nord. J. Bot. 12: $39-61$.

Pabst, G. F. J. \& Dungs, F. (1975). Orchidaceae Brasilienses, v.1. Brucke, Hildesheim.

Ratter, J. A., Ribeiro, J. F. \& Bridgewater, S. (1997). The Brazilian cerrado vegetation and threats to its biodiversity. Ann. Bot. 80: 223 - 230.

Renz, J. (1992). The genus Habenaria (Orchidaceae) in the Guianas. Candollea 47: 483 - 512. 